\title{
Evaluation of the anticarcinogenic potential of the endophyte, Streptomyces sp. LRE541 isolated from Lilium davidii var. unicolor (Hoog) Cotton
}

\author{
Aiai Ma ${ }^{1,2}$, Kan Jiang ${ }^{5}$, Bin Chen ${ }^{5}$, Shasha Chen ${ }^{3}$, Xinge Qi ${ }^{1}$, Huining Lư ${ }^{4}$, Junlin Liư ${ }^{4}$ Xuan Zhou ${ }^{1,2}, \operatorname{Tan}_{\text {Gao }}{ }^{1,2}$, \\ Jinhui Li ${ }^{1}$ and Changming Zhao ${ }^{1,2^{*}}$ (i)
}

\begin{abstract}
Background: Endophytic actinomycetes, as emerging sources of bioactive metabolites, have been paid great attention over the years. Recent reports demonstrated that endophytic streptomycetes could yield compounds with potent anticancer properties that may be developed as chemotherapeutic drugs.

Results: Here, a total of 15 actinomycete-like isolates were obtained from the root tissues of Lilium davidii var. unicolor (Hoog) Cotton based on their morphological appearance, mycelia coloration and diffusible pigments. The preliminary screening of antagonistic capabilities of the 15 isolates showed that isolate LRE541 displayed antimicrobial activities against all of the seven tested pathogenic microorganisms. Further in vitro cytotoxicity test of the LRE541 extract revealed that this isolate possesses potent anticancer activities with $I C_{50}$ values of $0.021,0.2904,1.484,4.861,6.986$, 8.106, 10.87, 12.98, and $16.94 \mathrm{\mu g} / \mathrm{mL}$ against cancer cell lines RKO, 7901, HepG2, CAL-27, MCF-7, K562, Hela, SW1990, and A549, respectively. LRE541 was characterized and identified as belonging to the genus Streptomyces based on the 165 rRNA gene sequence analysis. It produced extensively branched red substrate and vivid pink aerial hyphae that changed into amaranth, with elliptic spores sessile to the aerial mycelia. To further explore the mechanism underlying the decrease of cancer cell viability following the LRE541 extract treatment, cell apoptosis and cell cycle arrest assays were conducted in two cancer cell lines, RKO and 7901. The result demonstrated that LRE541 extract inhibited cell proliferation of RKO and 7901 by causing cell cycle arrest both at the S phase and inducing apoptosis in a dosedependent manner. The chemical profile of LRE541 extract performed by the UHPLC-MS/MS analysis revealed the presence of thirty-nine antitumor compounds in the extract. Further chemical investigation of the LRE541 extract led to the discovery of one prenylated indole diketopiperazine (DKP) alkaloid, elucidated as neoechinulin A, a known antitumor agent firstly detected in Streptomyces; two anthraquinones 4-deoxy- $\varepsilon$-pyrromycinone (1) and epsilon-pyrromycinone (2) both displaying anticancer activities against RKO, SW1990, A549, and HepG2 with IC 50 values of $14.96 \pm 2.6$ $-20.42 \pm 4.24 \mu \mathrm{g} / \mathrm{mL}$ for (1); $12.9 \pm 2.13,19.3 \pm 4.32,16.8 \pm 0.75$, and $18.6 \pm 3.03 \mu \mathrm{g} / \mathrm{mL}$ for (2), respectively.
\end{abstract}

Conclusion: Our work evaluated the anticarcinogenic potential of the endophyte, Streptomyces sp. LRE541 and obtained one prenylated indole diketopiperazine alkaloid and two anthraquinones. Neoechinulin A, as a known

\footnotetext{
*Correspondence: zhaochm@lzu.edu.cn

1 State Key Laboratory of Grassland Agro-Ecosystems, School of Life

Sciences, Lanzhou University, Lanzhou 730000, Gansu, China

Full list of author information is available at the end of the article
}

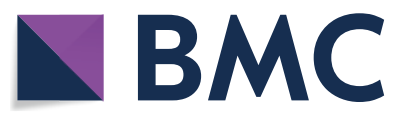

(c) The Author(s) 2021. Open Access This article is licensed under a Creative Commons Attribution 4.0 International License, which permits use, sharing, adaptation, distribution and reproduction in any medium or format, as long as you give appropriate credit to the original author(s) and the source, provide a link to the Creative Commons licence, and indicate if changes were made. The images or other third party material in this article are included in the article's Creative Commons licence, unless indicated otherwise in a credit line to the material. If material is not included in the article's Creative Commons licence and your intended use is not permitted by statutory regulation or exceeds the permitted use, you will need to obtain permission directly from the copyright holder. To view a copy of this licence, visit http://creativecommons.org/licenses/by/4.0/. The Creative Commons Public Domain Dedication waiver (http://creativeco mmons.org/publicdomain/zero/1.0/) applies to the data made available in this article, unless otherwise stated in a credit line to the data. 
antitumor agent, was identified for the first time in Streptomyces. Though previously found in Streptomyces, epsilonpyrromycinone and 4-deoxy- $\varepsilon$-pyrromycinone were firstly shown to possess anticancer activities.

Keywords: Endophytic Streptomyces sp. LRE541, Bioactive metabolites, Indole diketopiperazine alkaloid, Anthraquinones, Anticancer activity, Cell apoptosis, Cell cycle

\section{Graphical Abstract}

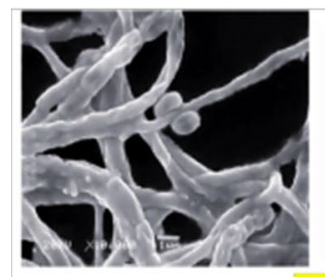

(1) Examination of antagonistic activity of LRE541

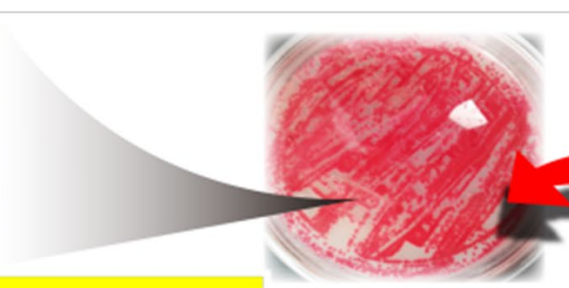

Streptomyces sp. LRE541

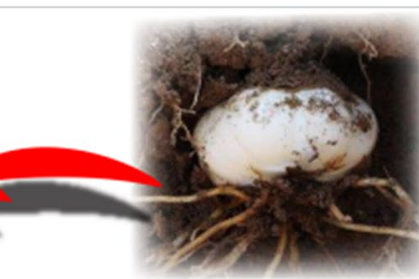

Lilium davidii var. unicolor (Hoog) Cotton

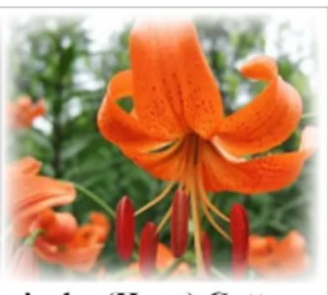

(2) Up-scale fermentation and Extraction
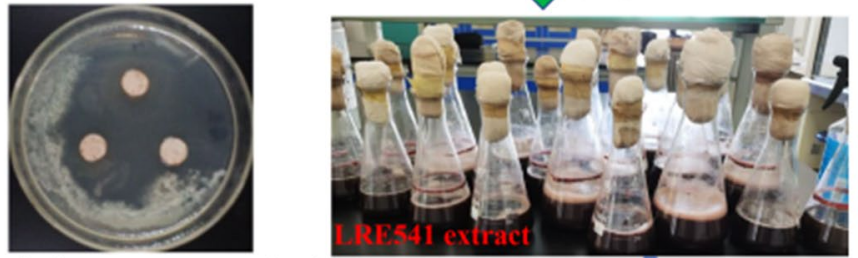

Anti-Staphylococcus saprophyticus
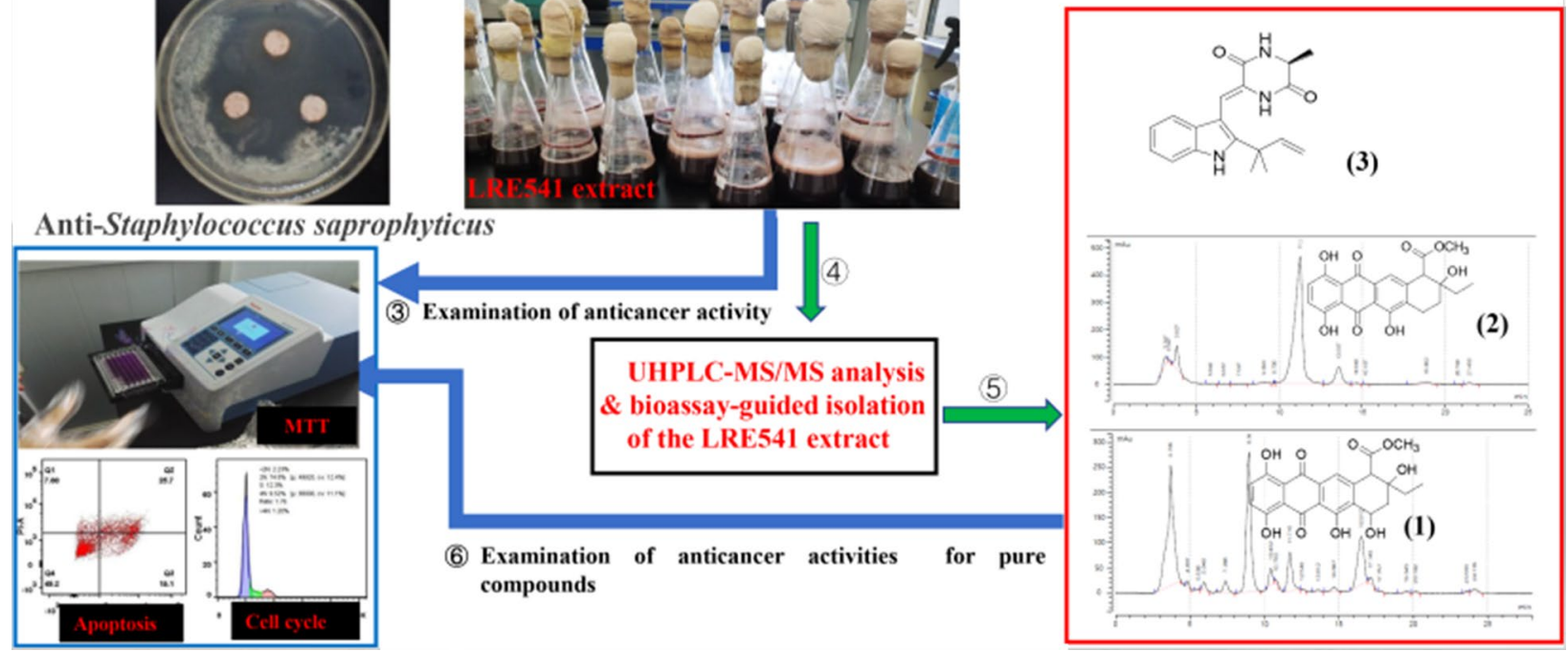

(3)

\section{Introduction}

Although major progress has been achieved in cancer therapy for the past few decades, cancer remains a serious public health threat [1]. Chemotherapy is one of the common therapeutic approaches for controlling cancers. Unfortunately, most patients eventually relapse and develop drug resistance [2,3]. On this account, a continuous supply of novel drugs with high effectiveness and safety is urgently needed. Besides, drug-induced apoptosis of malignant cells is a promising antitumor strategy with emerging evidence supporting its efficacy against various cancer types [4-6]. Thus, extensive and intensive studies on the underlying antitumor mechanisms of the drugs are also required.

The genus Streptomyces, with its vast distribution and innate capability of producing diverse bioactive secondary metabolites, has served as an important source of novel antibiotic candidates for decades [7-9]. Nowadays, exploiting streptomycetes from untapped or unique ecosystems may be an effective way to meet the everlasting demand for novel drugs and other biomolecules, which have been preferred attributing to their potent therapeutic applications and desired pharmacokinetic properties for clinical uses and served as precursors of drug semi-synthesis or the template of drug chemical synthesis $[10,11]$. Over the past decade, endophytic streptomycetes from medicinal plants in various ecotopes, as relatively unexploited fascinating sources of novel natural products, have been explored extensively and gained some remarkable results. For example, reports covering new endophytic Streptomyces species and their novel secondary metabolites along with antimicrobial and antioxidant activities have sprung up [11-14]. Moreover, endophytic streptomycetes 
have been reported to possess anticancer activities as well. Although such reports are sporadic compared to marine actinomycetes, the anticancer effects or cytotoxic activities of endophytic streptomycetes are comparable to those of their marine counterparts, even stronger $[15,16]$. In addition, it is widely accepted that medicinal plants are rich sources of precious bioactive compounds, and increasing evidence indicates that endophytic actinomycetes may participate in the metabolic pathways of their host plants and obtain some genetic information to yield bioactive compounds similar to their host plants $[17,18]$. These findings suggest that bioprospecting of endophytic streptomycetes from medicinal plants may be a good choice for anticarcinogens discovery.

Lilium davidii var. unicolor (Hoog) Cotton (commonly called Lanzhou lily), a famous healthcare edible medicinal plant rich in amino acid, vitamins, glycosides, alkaloids, and polysaccharides, possesses antioxidant activities [19]. Accordingly, the actinomycetes from the plants may develop adaptive strategies and yield chemically unique secondary metabolites. However, there is no report concerning the anticancer activities of Streptomyces species from L. davidii var. unicolor (Hoog) Cotton in vitro. Given the immense potential of the secondary metabolites of endophytic actinomycetes for pharmaceutical applications, we isolated and characterized actinomycetes from the root tissues of $L$. davidii var. unicolor (Hoog) Cotton, and investigated the antimicrobial capabilities of the isolates. The most potent isolate was screened for evaluating antitumor activities, as well as the inductive effects on apoptosis and cell cycle arrests of tumor cells. Further, the active compounds from the isolate were purified and characterized.

\section{Results}

\section{Isolation of endophytic actinomycetes and screening} for antimicrobial activities

On the basis of colonial morphology, mycelia coloration and diffusible pigments, fifteen actinomycete-like isolates with representative phenotypes were obtained from the root tissues of $L$. davidii var. unicolor (Hoog) Cotton. The preliminary screening of antimicrobial capabilities showed that two isolates had exhibited antagonistic activities against at least four of the tested pathogenic microorganisms (Additional file 1: Table S1), especially LRE541 isolate against all the tested Gram-positive/-negative bacteria and the yeast-like fungus with the maximum activity against Staphylococcus saprophyticus (inhibition zone of $21.33 \mathrm{~mm}$ diameter) (Table 1). Thus, LRE541 isolate was selected for up-scale fermentation and extraction of secondary metabolites for further assessments.
Table 1 Antimicrobial activities of isolate LRE541 against various pathogenic microorganisms

\begin{tabular}{lc}
\hline Test microorganisms & $\begin{array}{c}\text { Inhibition zone } \\
\text { (mm diameter) }\end{array}$ \\
\hline Gram-positive bacteria & $16.67 \pm 2.31$ \\
Staphylococcus aureus (MRSA) ATCC25923 & $16 \pm 2.65$ \\
$\quad$ Diplococcus pneumoniae (clinical isolate) & $12.33 \pm 0.58$ \\
$\quad$ Enterococcus faecalis (clinical isolate) & $21.33 \pm 1.53$ \\
$\quad$ Staphylococcus saprophyticus (clinical isolate) & \\
Gram-negative bacteria & $12.33 \pm 1.53$ \\
$\quad$ Escherichia coli ATCC25922 & $12 \pm 1.00$ \\
$\quad$ Pseudomonas aeruginosa ATCC27853 & \\
The yeast-like fungus & $7.67 \pm 0.78$ \\
$\quad$ Candida albicans ATCC66415 &
\end{tabular}

\section{Phenotypic characteristics of isolate LRE541}

The isolate LRE541 obtained from the root tissues of $L$. davidii var. unicolor (Hoog) Cotton was Gram-positive and aerobic. The cultural characteristics of LRE541 on various media were shown in Table 2 . It grew well on all the tested media (ISP2-ISP7 and Gauze's No. 1) with varying aerial and substrate mycelia colors on different media. Compared with ISPs, the diffusible pigment was only produced on the Gauze's No. 1 medium. As presented under the scanning electron microscopy in Fig. 1, isolate LRE541 produced elliptic spores sessile to the aerial hyphae, which extensively branched and grew in segments with verrucous protrusions. As shown in Table 3, the growth of LRE541 was observed at the temperature range of $18-37^{\circ} \mathrm{C}$ (optimum at $23^{\circ} \mathrm{C}$ ), and the $\mathrm{pH}$ range of 4-12; however, at $\mathrm{NaCl}$ concentration above $6 \%(\mathrm{w} / \mathrm{v})$, no growth was observed. Isolate LRE541 was positive for cellulose utilization but negative for both methyl red test and $\mathrm{H}_{2} \mathrm{~S}$ production. In the extracellular enzyme activity tests, the isolate LRE541 demonstrated to produce various enzymes such as urease, catalase, amylase, protease, and lipase. Furthermore, it was found that LRE541 had broad utilization of carbon and nitrogen sources (Table 3). These phenotypic properties of LRE541 were in close similarity with the genus Streptomyces as depicted by Barka et al. [20] in that they are prolific aerobic Grampositive bacteria possessing extensively branched vegetative form and aerial hyphae and produce various water-soluble pigments.

\section{S rRNA gene-based phylogenetic analysis}

The almost complete $16 \mathrm{~S}$ rRNA gene sequencing revealed that isolate LRE541 comprised $1471 \mathrm{bp}$, which was submitted in GenBank/EMBL/DDBJ under the accession number MK138546 (https://www.ncbi.nlm.nih. 
Table 2 Cultural characteristics of Streptomyces sp. LRE541 on various media

\begin{tabular}{lllll}
\hline Media & Growth & Color of colony mycelia & Diffusible pigment \\
\cline { 3 - 4 } & & Aerial & Substrate & - \\
\hline ISP2 & Good & Light pink to red & Orange-yellow to red & - \\
ISP3 & Good & Bright red & Red & - \\
ISP4 & Good & Pinky white & Pinky white & - \\
ISP5 & Good & Red in white & Red in white & - \\
ISP6 & Good & Transparent to pale violet red & Pale violet red & - \\
ISP7 & Good & Brick red & Vivid red & Claret-colored pigment \\
Gause's No. 1 & Good & Vivid pink & Red & \\
\hline
\end{tabular}

- , absent

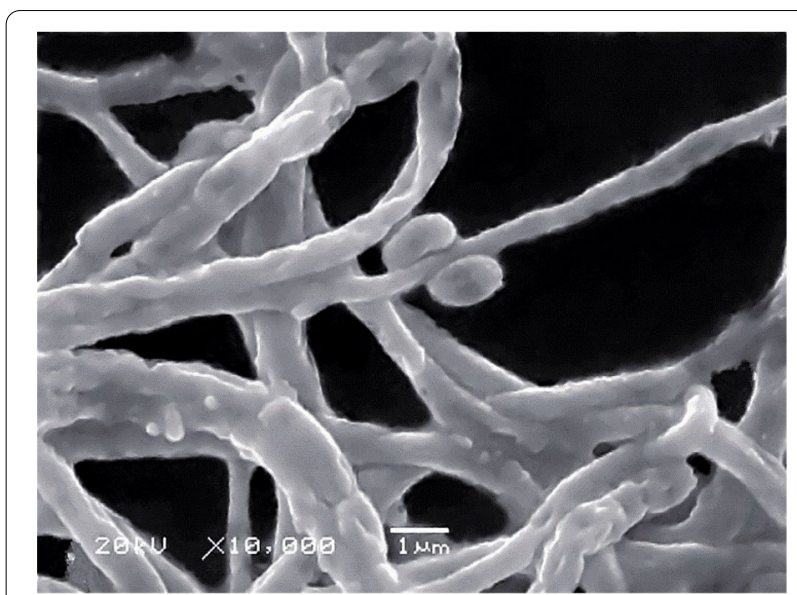

Fig. 1 The scanning electron micrograph of Streptomyces sp. LRE541 cultured on the Gauze's No. 1 medium for 2 weeks showing aerial mycelia and spores

gov/nuccore/MK138546). The 16S rRNA gene sequence of LRE541 was aligned with those of the type strains retrieved from GenBank/EMBL/DDBJ databases. As presented in Fig. 2, the phylogenetic tree demonstrated that LRE541 formed a distinct phyletic line with the type strain Streptomyces tauricus JCM $4837^{\mathrm{T}}$ at bootstrap value of $85 \%$, displaying the highest $16 \mathrm{~S}$ rRNA gene sequence similarity value with Streptomyces tauricus JCM $4837^{\mathrm{T}}$ (98.81\%), and followed by Streptomyces ederensis NBRC15410 ${ }^{\mathrm{T}}$ (98.45\%), Streptomyces dioscori A $217^{\mathrm{T}}$ (98.25\%), Streptomyces aurantiacus $\mathrm{NBRC} 13017^{\mathrm{T}}$ (98.18\%), and Streptomyces glomeroaurantiacus NBRC15418 ${ }^{\mathrm{T}}$ (98.12\%).

\section{Cytotoxicity of the LRE541 extract towards various cell lines}

We had determined the cytotoxicity of LRE541 extract towards a panel of cancer cell lines (A549, SW1990, HepG2, CAL-27, MCF-7, 7901, RKO, Hela, and K562) and one normal cell line human pulmonary artery endothelial cell (HPAEC). As illustrated in Table 4, the LRE541 extract exhibited cytotoxic activities against six cancer cell lines with $\mathrm{IC}_{50}$ values $<10 \mu \mathrm{g} / \mathrm{mL}$, and against all of the cancer cell lines with $\mathrm{IC}_{50}$ values $(0.021-16.94 \mu \mathrm{g} / \mathrm{mL})<20 \mu \mathrm{g} / \mathrm{mL}$. Among the nine tested cancer cell lines, the LRE541 extract demonstrated the most potent efficacy towards RKO, followed by 7901 and HepG2 with $\mathrm{IC}_{50}$ values of 0.021, 0.29, and $1.484 \mu \mathrm{g} /$ $\mathrm{mL}$, respectively, after $48 \mathrm{~h}$ treatment. Compared to the cytotoxicity against HPAEC with $\mathrm{IC}_{50}$ value of $20.14 \mu \mathrm{g} /$ $\mathrm{mL}$, the LRE541 extract displayed a greater cytotoxicity towards RKO, 7901, and HepG2 in vitro. In conclusion, the LRE541 extract potently inhibited various cell types with a high preference for RKO and 7901. Thus, RKO and 7901 were opted to furtherly investigate the effect of LRE541 extract on cancer cells. As illustrated in Fig. 3, compared to HPAEC, the cell viabilities of RKO and 7901 dramatically decreased when the concentration of the LRE541 extract was within $10 \mu \mathrm{g} / \mathrm{mL}$, and below $30 \%$ when reached $10 \mu \mathrm{g} / \mathrm{mL}$.

\section{Induction of apoptosis in 7901 and RKO cell lines}

Inducing apoptosis and necrosis of tumor cells is the primary mechanism of chemotherapeutic drugs inhibiting tumors, and it is also one of the leading indicators for evaluating the efficacy of chemotherapeutic drugs $[21,22]$. Herein, we quantitatively detected the cell death type triggered by the LRE541 extract in 7901 and RKO cell lines using the annexin V-FITC and PI double staining, which were presented in Fig. 4a. After the cells were processed with the LRE541 extract $(2 \mu \mathrm{g} / \mathrm{mL})$ for $48 \mathrm{~h}$, FITC-positive cells accounted for $\sim 50 \%$ and $\sim 40 \%$ of the total cells in 7901 and RKO, respectively, suggesting that apoptosis was a major mechanism of the cytotoxicity of the LRE541 extract whether in 7901 or RKO cell line, and the LRE541 extract induced apoptotic cell death in a dose-dependent manner in both two cell lines (Fig. 4b). However, the apoptosis patterns of the RKO 
Table 3 Physiological properties of Streptomyces sp. LRE541

\begin{tabular}{|c|c|c|c|}
\hline Tests & Results & Tests & Results \\
\hline Cellulose utilization & + & Nitrogen sources utilization & \\
\hline MR test & - & Urea & + \\
\hline $\mathrm{H}_{2} \mathrm{~S}$ production & - & Glycine & + \\
\hline Extracellular enzyme activity & & Peptone & + \\
\hline Urease & + & Maizena & - \\
\hline Catalase & + & Tyrosine & + \\
\hline Starch hydrolysis & + & Aspartic acid & - \\
\hline Gelatin hydrolysis & + & Soybean meal & + \\
\hline Degradation of & & Ammonium sulfate & + \\
\hline Tween 20 & - & L-Proline & + \\
\hline Tween 40 & + & L-Arginine & + \\
\hline Tween 80 & + & L-a-Alanine & - \\
\hline Carbon sources utilization & & Growth at $\mathrm{pH}$ & \\
\hline Xylose & ++ & $\mathrm{pH} 2$ & - \\
\hline Starch & + & $\mathrm{pH} 4$ & + \\
\hline Glucose & ++ & $\mathrm{pH} 6$ & + \\
\hline Maltose & +++ & $\mathrm{pH} 7$ & +++ \\
\hline Lactose & +++ & $\mathrm{pH} 8$ & ++ \\
\hline Sucrose & ++ & $\mathrm{pH} 10$ & ++ \\
\hline Fructose & + & $\mathrm{pH} 12$ & +++ \\
\hline Mannose & ++ & Growth at Temp & \\
\hline Trehalose & - & $4-16^{\circ} \mathrm{C}$ & - \\
\hline Raffinose & - & $18-20^{\circ} \mathrm{C}$ & + \\
\hline Arabinose & + & $23^{\circ} \mathrm{C}$ & +++ \\
\hline Rhamnose & + & $28^{\circ} \mathrm{C}$ & ++ \\
\hline Growth at $\mathrm{NaCl}(\mathrm{w} / \mathrm{v})$ & & $37^{\circ} \mathrm{C}$ & + \\
\hline $0-6 \%$ & ++ & Gram staining & + \\
\hline
\end{tabular}

"-", negative test; "+", positive test/slight growth;"++", well-growth;" +++ ", very well growth

and 7901 were distinctly diverse. As demonstrated in Fig. 4c, for the 7901, the proportion of early apoptotic cells was higher than that of late apoptotic cells at low concentration of the LRE541 extract; however, the number of early apoptotic cells gradually decreased as the concentration increased, while the number of late apoptotic cells sharply increased with the increased concentration of LRE541 extract. In contrast, for the RKO cell line, the late apoptotic cells were dominant at first and displayed a dose-dependent manner, while the number of early apoptotic cells slightly increased with the increasing concentration.

\section{The LRE541 extract inhibits the cell cycles of 7901 and RKO} cell lines

Flow cytometric analysis of DNA showed a dosedependent accumulation of cells in the $\mathrm{S}$ phase of the cell cycle both in 7901 and RKO cell lines, with a concomitant decrease in the proportion of cells in the $\mathrm{G}_{0} /$ $G_{1}$ phase when treated with a concentration gradient of the LRE541 extract for $48 \mathrm{~h}$, indicating the LRE541 extract blocked the cell cycle of 7901 and RKO in S phase (Fig. 5a, b).

\section{Chemical profiling of the LRE541 extract using UHPLC-MS/ MS analysis}

To examine the compounds that may be responsible for its antineoplastic properties, the LRE541 extract was subjected to ultra-high performance liquid chromatographytandem mass spectrometry (UHPLC-MS/MS) analysis (Additional file 1: Fig. S1), which detected the presence of approximately 700 compounds in the LRE541 extract. More than a seventh of the compounds were documented to exhibit various biological activities, including thirty-nine antitumor compounds, ten antioxidant compounds, and sixteen antimicrobial compounds. The detailed information of the sixty-five compounds, including retention time, molecular formula, molecular weight, and relative ratio, was listed in Additional file 1: Table S2 


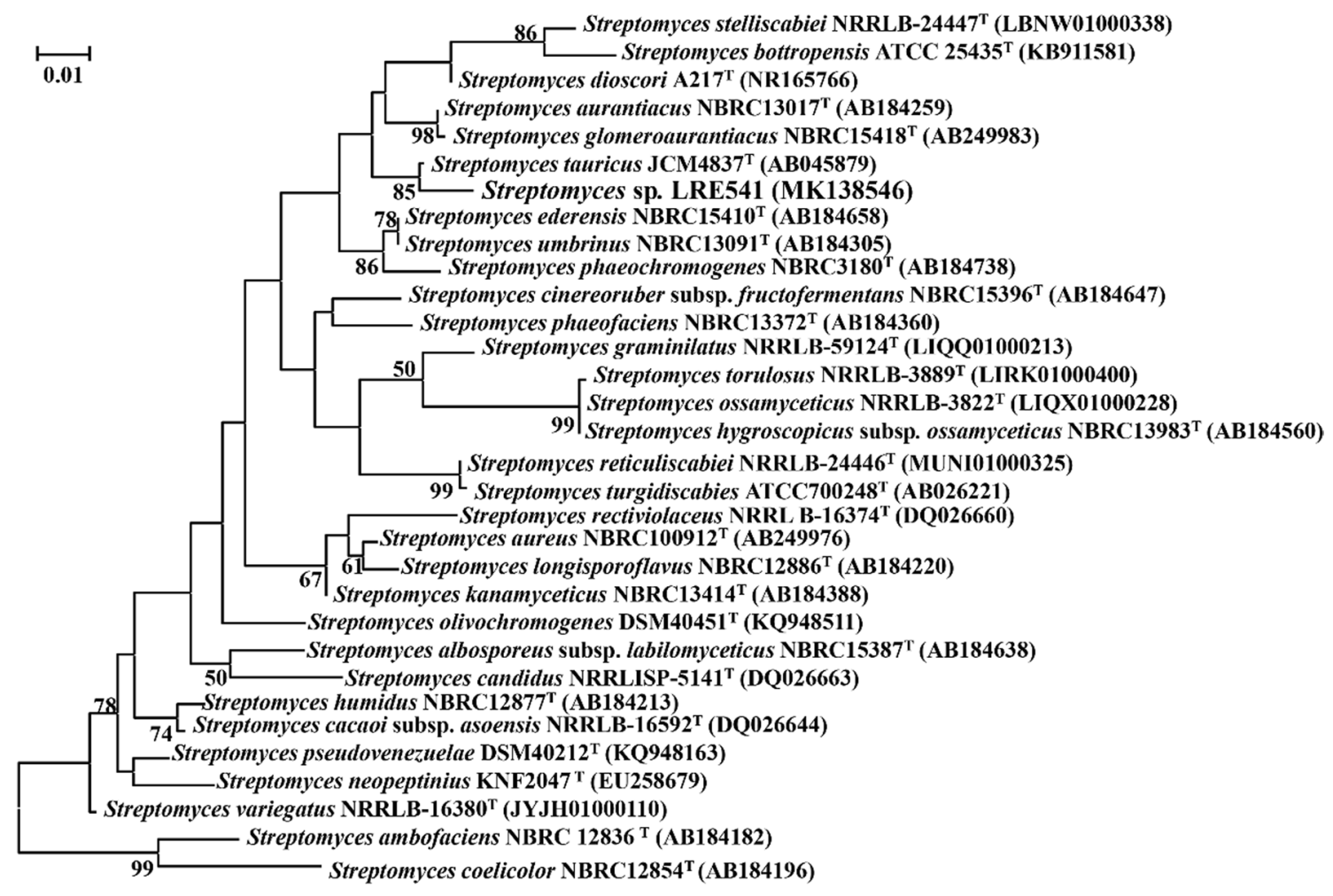

Fig. 2 Maximum Likelihood tree exhibiting phylogenetic relationship between isolate LRE541 and the closely related representatives of Streptomyces spp. Only bootstrap values above $50 \%$ are present at the tree nodes. The scale bar denotes 0.01 substitutions per site

Table $4 I C_{50}$ values of the LRE541 extract against various cell lines $(\mu \mathrm{g} / \mathrm{mL})$

\begin{tabular}{ll}
\hline Cell types & IC $_{50}$ \\
\hline Human colon cell RKO & 0.02127 \\
Human gastric adenocarcinoma 7901 & 0.2904 \\
Human liver carcinoma cell HepG2 & 1.484 \\
Human tongue cancer cell CAL-27 & 4.861 \\
Human breast carcinoma cell MCF-7 & 6.986 \\
Human chronic promyelocytic leukemia cell K562 & 8.106 \\
Human cervical cancer cell Hela & 10.87 \\
Human pancreatic cancer cell SW1190 & 12.98 \\
Human non-small cell lung cancer A549 & 16.94 \\
Human pulmonary artery endothelial cell HPAEC (human & 20.14 \\
normal cell) & \\
\hline
\end{tabular}

and their chemical structures were presented in Additional file 1: Fig. S2.

\section{Structure elucidation and cytotoxicity of compounds from LRE541 extract}

The active fraction C4 (anticancer activity against SW1990 with $\mathrm{IC}_{50}$ value of $31.4 \mu \mathrm{g} / \mathrm{mL}$ ) was subjected to silica gel column, sephadex LH-20 column, and compound 3 was obtained from preparing thin-layer chromatography (TLC). The fraction C3 (anticancer activity against SW1990 with $\mathrm{IC}_{50}$ value of $81.35 \mu \mathrm{g} / \mathrm{mL}$ ) was re-chromatographed by semi-preparative HPLC till showing pure compounds at $11.263 \mathrm{~min}$ and $8.965 \mathrm{~min}$ to obtain compound 1 and 2 as seen in Fig. 6a, b. Based on 1D and 2D NMR spectroscopic analyses (Table 5, Additional file 1: Figs. S3-S10) and by comparison with those reported in the literatures, the three pure components were identified as two anthraquinone compounds 4-deoxy- $\varepsilon$-pyrromycinone (1), epsilon-pyrromycinone (2), and neoechinulin A (3), a prenylated diketopiperazine alkaloid. The chemical structures of the three compounds were depicted in Fig. 6c.

Neoechinulin A had been repeatedly reported to be cytotoxic to at least seven cancer cell lines [23, 24]. Thus, we mainly evaluated the antitumor activities of compounds (1) and (2), which showed cytotoxic activities against RKO, A549, HepG2, and SW1990 with $\mathrm{IC}_{50}$ values in the range of $14.96 \pm 2.6$ to $20.42 \pm 4.24 \mu \mathrm{g} /$ $\mathrm{mL}$ for $(1)$ and $12.9 \pm 2.13,19.3 \pm 4.32,16.8 \pm 0.75$, and $18.6 \pm 3.03 \mu \mathrm{g} / \mathrm{mL}$ for (2) (Table 6). The antitumor activities of 4-deoxy- $\varepsilon$-pyrromycinone and epsilon-pyrromycinone both displayed a preference for RKO cell line, slightly superior to cisplatin. 

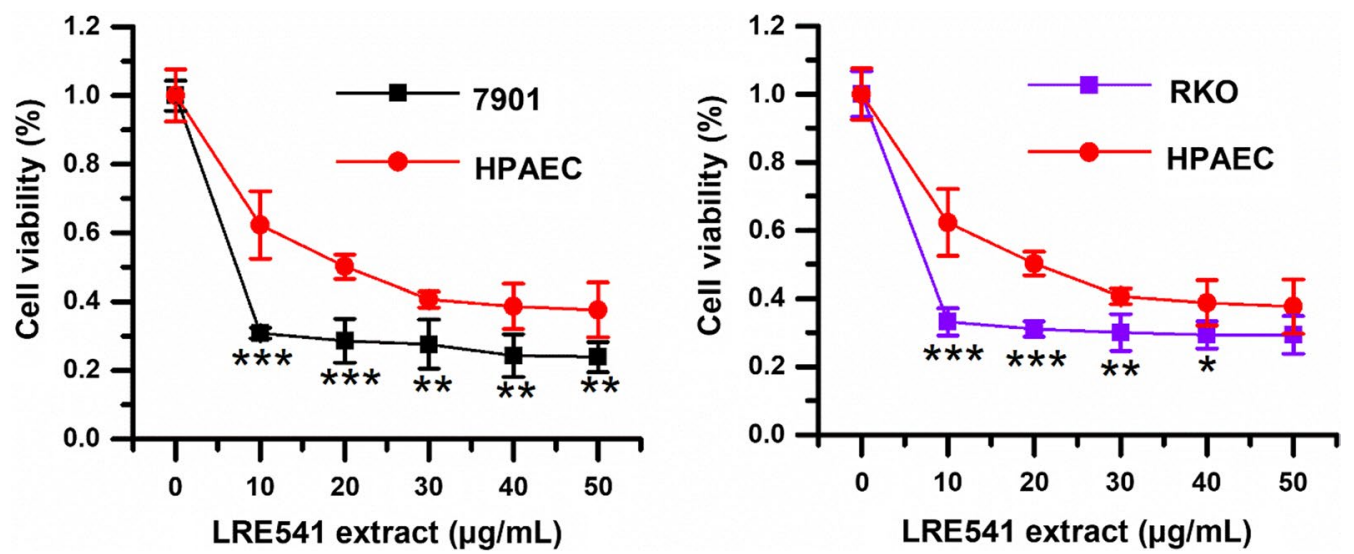

Fig. 3 Sensitivity of various types of cell lines (7901, RKO and HPAEC) to the LRE541 extract. The three cell lines were incubated with increasing concentrations of the LRE541 extract for $48 \mathrm{~h}$, and their viabilities were determined by the MTT method. ${ }^{*} P<0.05$, ${ }^{* *} P<0.01,{ }^{* * *} P<0.001$ vs. the HPAEC cell line

a

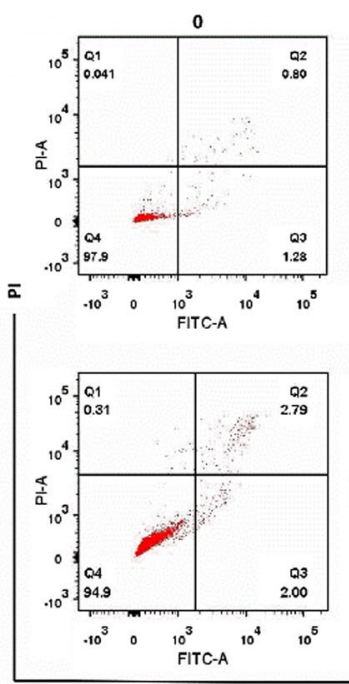

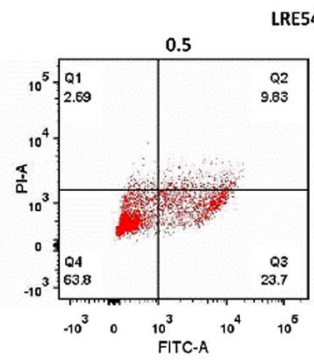

LRE541 extract $(\mu \mathrm{g} / \mathrm{mL})$
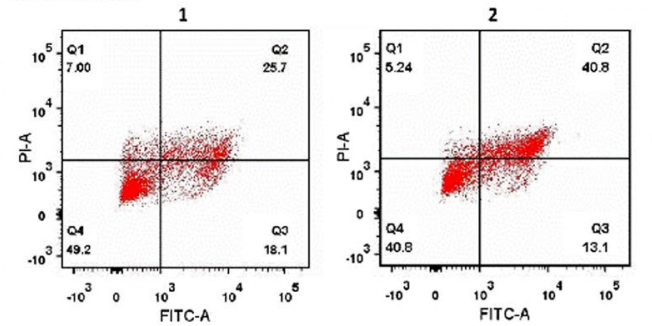

7901
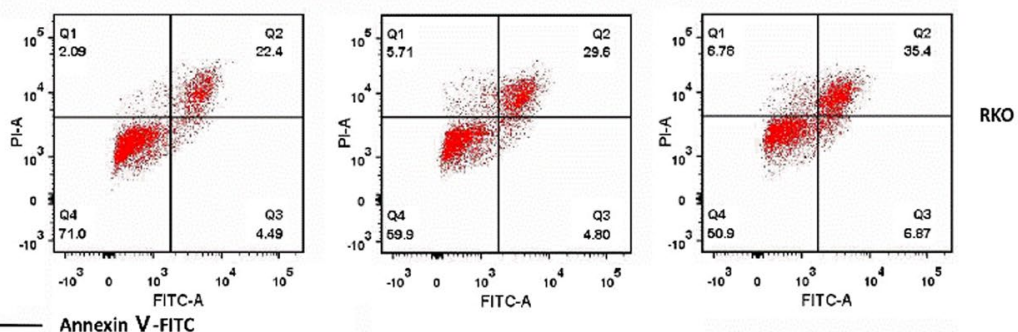

b
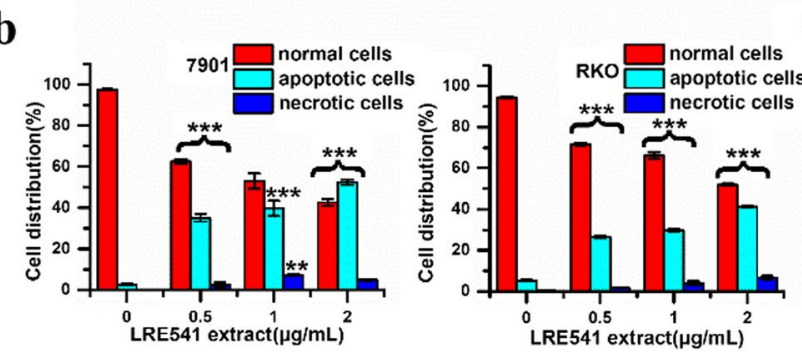

C
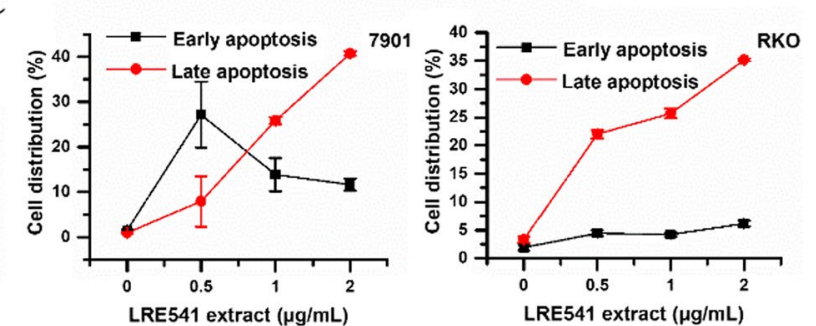

Fig. 4 The LRE541 extract induces apoptosis in RKO and 7901 cell lines. a The apoptotic cells change in RKO and 7901 cell lines when treated with increasing concentrations of the LRE541 extract for $48 \mathrm{~h}$ by Annexin $\mathrm{V}$ and PI double-staining assay. $\mathbf{b}$ The quantification of necrotic cells, apoptotic cells and normal cells. The data are presented as the mean \pm SD of three independent experiments. ${ }^{*} P<0.05,{ }^{* *} P<0.01,{ }^{* * *} P<0.001$ vs. the control groups. c Early and late apoptotic cells of 7901 and RKO treated with varying concentrations of the LRE541 extract for $48 \mathrm{~h}$ 

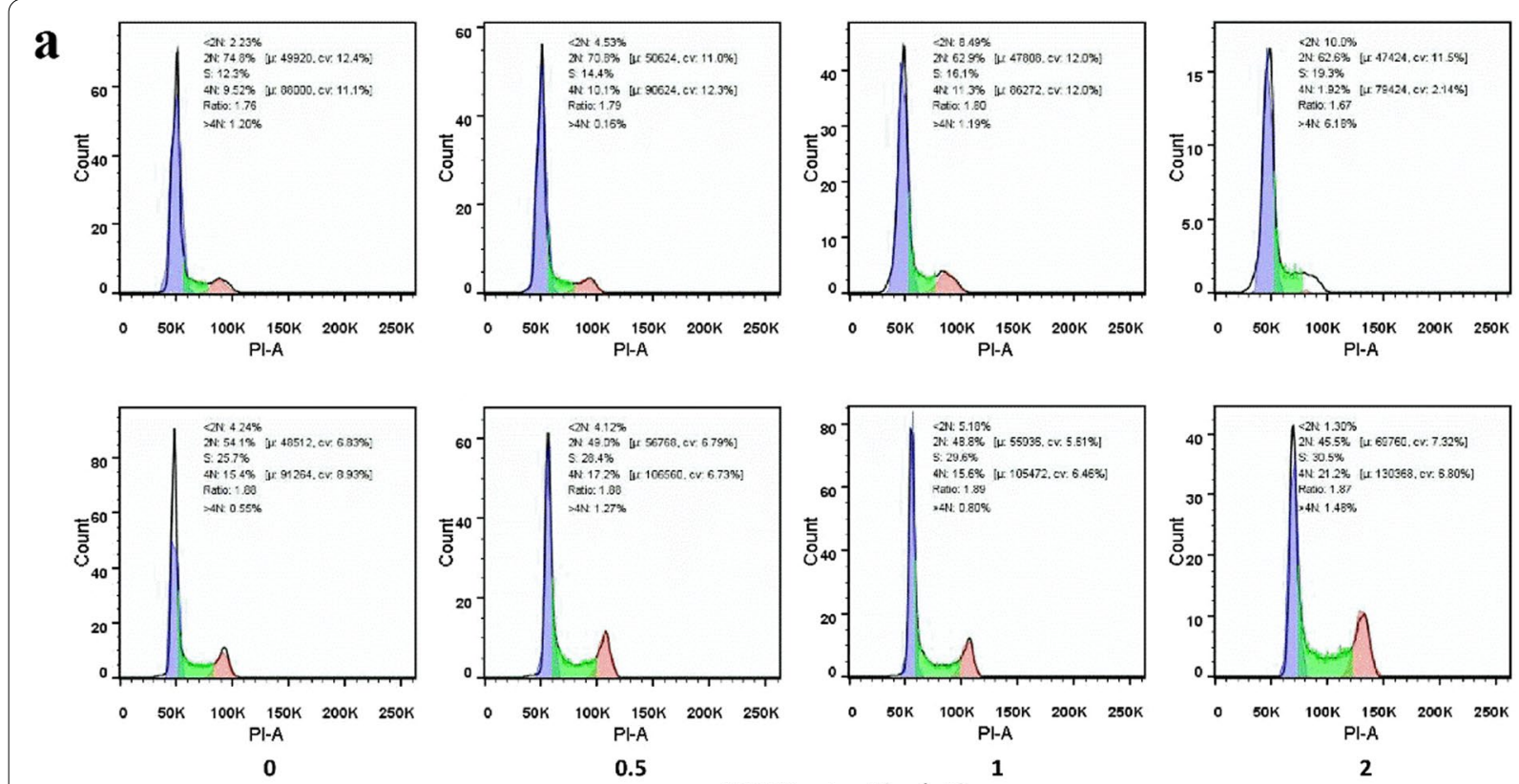

7901
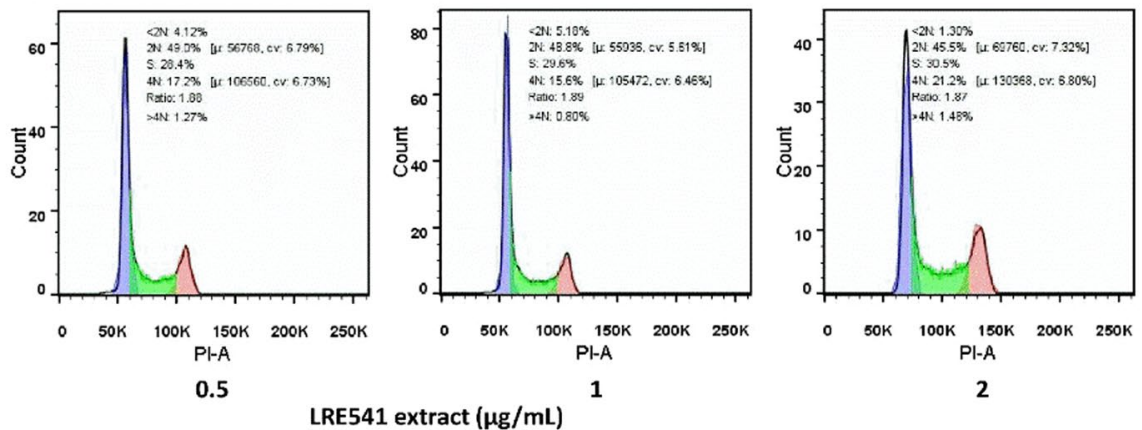

RKO

b
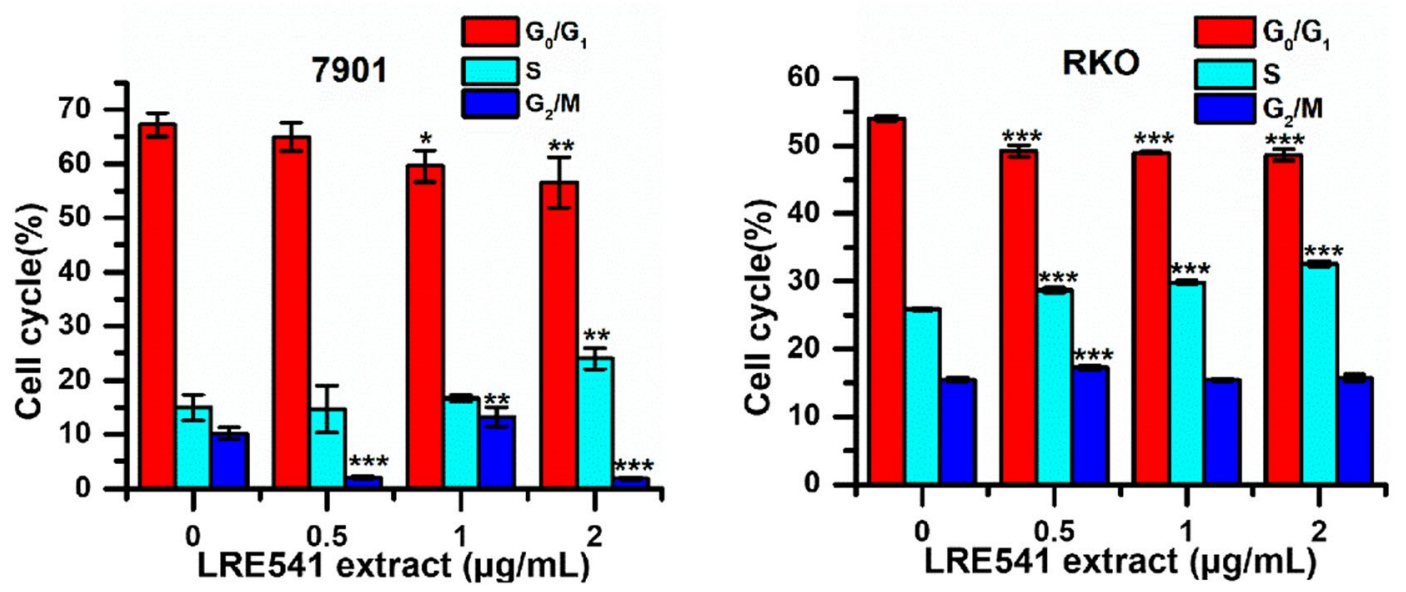

Fig. 5 Effects of the LRE541 extract on cell cycles of RKO and 7901. a Cell cycle progressions of 7901 and RKO when treated with increasing concentrations of the LRE541 extract for $48 \mathrm{~h}$. b Quantification of living cells distributing in three distinct phases of the cell cycle $\left(G_{0} / G_{1}, S\right.$, and $G_{2} / M$ phase). The data are shown as the mean $\pm S D$ of three independent experiments. ${ }^{*} P<0.05,{ }^{* *} P<0.01,{ }^{* * *} P<0.001$ vs. the control groups

\section{Discussion}

Our study got fifteen actinomycete-like isolates from the root tissues of $L$. davidii var. unicolor (Hoog) Cotton. The preliminary screening of antagonistic capabilities of the 15 isolates found that isolate LRE541 showed antimicrobial activities against all of the tested pathogenic microorganisms. Thus, LRE541 isolate was furtherly evaluated for the anticarcinogenic potential against a variety of malignancies.

\section{Description of Streptomyces sp. LRE541}

The isolate LRE541, well-characterized by the comparative analysis of $16 \mathrm{~S}$ rRNA gene sequence, was assigned to Streptomyces sp. The phylogenetic relationship demonstrated that isolate LRE541 formed a distinct branch with the highest $16 \mathrm{~S}$ rRNA gene sequence similarity of $98.81 \%$ to the type strain Streptomyces tauricus $\mathrm{JCM} 4837^{\mathrm{T}}$. Phenotypically, isolate LRE541 grew well on all the tested media with diverse aerial and substrate mycelia but produced red diffusible pigment 


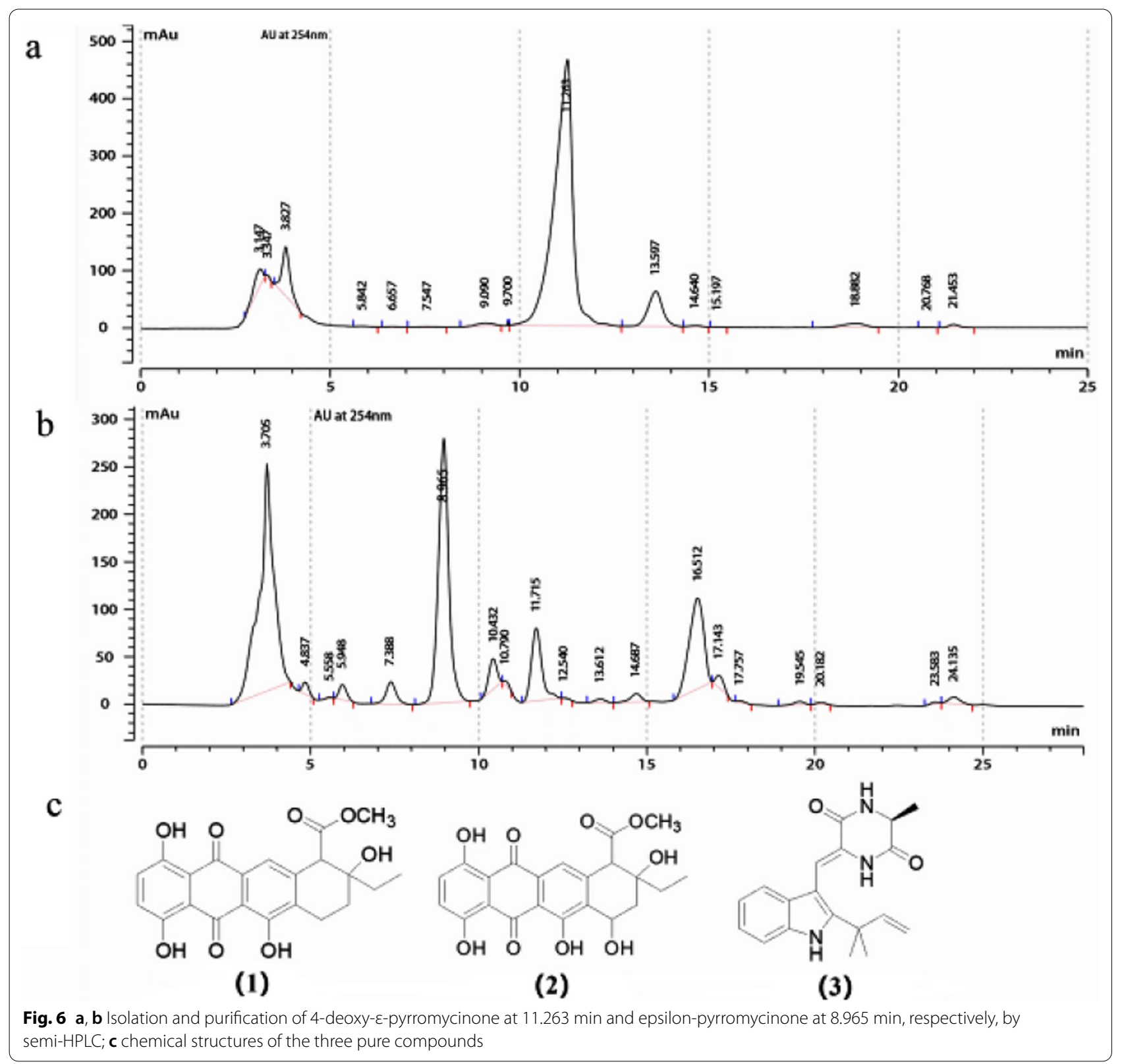

only on the Gauze's No. 1 medium. The extracellular enzyme tests found that LRE541 had the potential to yield various enzymes such as protease, amylase, and lipase, which are industrially important. In addition, LRE541 could tolerate a high $\mathrm{pH}$ value up to 12.0, a salinity of $6 \%(\mathrm{w} / \mathrm{v}) \mathrm{NaCl}$, and a temperature up to $37^{\circ} \mathrm{C}$. In sum, these physiological traits are similar to the characteristics of streptomycetes that they are prolific and possess the high adaptive capability for surviving in many unique niches [25-27], what's more, reflecting the physiological flexibility of Streptomyces isolate to adverse environmental conditions [28, 29]. Furthermore, the availability of a broad spectrum of carbon and nitrogen sources plays a vital role in producing diverse secondary metabolites by Streptomyces sp. [30]. Here, isolate LRE541 also exhibited the capability to utilize a wide range of carbon and nitrogen sources. This data provided an overview of the metabolite profile of LRE541, potentially serving as references for future research concerning fermentation optimization for a higher yield of the desirable bioactive metabolites. 
Table $5{ }^{13} \mathrm{C}$ NMR spectroscopic data of compounds (1)-(3) [400 MHz, $\delta$ (ppm)] purified from the LRE541extract

\begin{tabular}{|c|c|c|c|c|c|}
\hline \multicolumn{2}{|c|}{ (1) $\left(\mathrm{CDCl}_{3}\right)$} & \multicolumn{2}{|c|}{ (2) $\left(\mathrm{CDCl}_{3}\right)$} & \multicolumn{2}{|c|}{ (3) $\left(\left(\mathrm{CD}_{3}\right)_{2} \mathrm{CO}\right)$} \\
\hline Position & $\delta_{\mathrm{C}}$ & Position & $\delta_{\mathrm{C}}$ & Position & $\delta_{c}$ \\
\hline 1 & 159 & 1 & 158.6 & 2 & 144.8 \\
\hline 2 & 130 & 2 & 130.3 & 3 & 104.4 \\
\hline 3 & 129.7 & 3 & 129.8 & За & 126.6 \\
\hline 4 & 157.9 & 4 & 158 & 4 & 119.7 \\
\hline 5 & 191.2 & 5 & 191.1 & 5 & 120.7 \\
\hline 6 & 161.8 & 6 & 161.2 & 6 & 127.3 \\
\hline 7 & 20.3 & 7 & 62.6 & 7 & 110.7 \\
\hline 8 & 28.8 & 8 & 32 & $7 a$ & 136.2 \\
\hline 9 & 71.8 & 9 & 70.1 & 8 & 112.4 \\
\hline 10 & 57.3 & 10 & 57.6 & 9 & 122.2 \\
\hline 11 & 121 & 11 & 120.8 & 10 & 160.3 \\
\hline 12 & 186.5 & 12 & 185.3 & 12 & 52.2 \\
\hline 13 & 171.7 & 13 & 170.3 & 13 & 166.9 \\
\hline 14 & 53.4 & 14 & 53 & 15 & 40.1 \\
\hline 15 & 32.6 & 15 & 34.7 & $15 a \times 2$ & 27.9 \\
\hline 16 & 7 & 16 & 6.3 & 16 & 146 \\
\hline $4 a$ & 113 & $4 a$ & 112.5 & 17 & 112.3 \\
\hline $5 a$ & 131.3 & $5 a$ & 132.2 & & \\
\hline $6 a$ & 134.5 & $6 a$ & 132.8 & & \\
\hline $10 a$ & 142.1 & $10 a$ & 142.6 & & \\
\hline $11 a$ & 114 & $11 a$ & 114.9 & & \\
\hline $12 a$ & 112.9 & $12 a$ & 112.3 & & \\
\hline
\end{tabular}

Table $6 \mathrm{IC}_{50}$ values of the compounds 4-deoxy- $\varepsilon$ pyrromycinone (1), epsilon-pyrromycinone (2), and cisplatin (DDP) against various cancer cell lines $(\mu \mathrm{g} / \mathrm{mL})$. The data are shown as the mean \pm SD of three independent experiments

\begin{tabular}{lcccl}
\hline Compounds & A549 & HepG2 & SW1990 & RKO \\
\hline$(1)$ & $19.55 \pm 5.2$ & $20.42 \pm 4.24$ & $17.87 \pm 2.73$ & $14.96 \pm 2.6$ \\
$(2)$ & $16.8 \pm 0.75$ & $18.6 \pm 3.03$ & $19.3 \pm 4.32$ & $12.9 \pm 2.13$ \\
DDP & $12.8 \pm 0.37$ & $13.3 \pm 1.2$ & $17.1 \pm 2.8$ & $16.72 \pm 3.5$ \\
\hline
\end{tabular}

\section{Cytotoxic activities of the extract and pure compounds from LRE541}

In view of the remarkable antimicrobial activities and physiological capabilities mentioned above, the secondary metabolites (LRE541 extract) of LRE541 were examined against nine representative human malignant tumors in vitro. The result revealed that the LRE541 extract showed cytotoxic activity towards all of the tumor cell lines with $\mathrm{IC}_{50}<20 \mu \mathrm{g} / \mathrm{mL}$, which is within the cut-off point of cytotoxicity criteria recommended by the National Cancer Institute (NCI) for screening the cytotoxicity of crude plant extracts [31, 32]. Moreover, the LRE541 extract exhibited cytotoxic activity against approximately $70 \%$ of the examined cancer cell lines with $\mathrm{IC}_{50}<10 \mu \mathrm{g} / \mathrm{mL}$, and great antitumor potential against $\mathrm{RKO}, 7901$ with $\mathrm{IC}_{50}$ values of only 0.021 and $0.29 \mu \mathrm{g} /$ $\mathrm{mL}$, respectively. The potent antineoplastic capacities of the LRE541 extract suggested that the presence of bioactive agents in the extract may account for it. Based on the UHPLC-MS/MS analysis, the LRE541 extract was detected to contain thirty-nine antitumor-, ten antioxidant- and sixteen antimicrobial-compounds documented in numerous studies. Taking the metabolite profile as a reference and combining it with bioassay-guided isolation of the LRE541 extract, we obtained three bioactive compounds. Neoechinulin A, a prenylated indole diketopiperazine (DKP) alkaloid, was derived from the fungus Aspergillus species [33], and subsequently, it was isolated from a higher plant Bridelia ferruginea [23] and a marine-derived fungus Microsporum sp. [34]. Neoechinulin A had been demonstrated to be a valuable cancer cell growth inhibitor against seven cancer cell lines (KM20L2, NCI-H460, SF-295, BXPC-3, DU-145, OVCAR-3, and P388) with $\mathrm{GI}_{50}$ values in the range of 0.19-0.27 $\mu \mathrm{g} / \mathrm{mL}$ [23]. Moreover, neoechinulin A had been shown to inhibit Hela cell proliferation by inducing cell apoptosis through down-regulating of Bcl-2 expression, up-regulating of Bax expression, and activating the caspase- 3 pathway [24]. In addition, neoechinulin A was characterized by several bioactivities, including anti-oxidant [33], anti-inflammatory and anti-fouling activities $[35,36]$. So far, prenylated indole diketopiperazines as important biological agents or their precursors were often detected in fungi, while neoechinulin A had been found in fungi and plants only, our study adds Streptomyces sp. as a new source for prenylated indole diketopiperazine production. Recently, anthraquinones were frequently detected in streptomycetes isolated from extreme or special environments such as marine, termites and plant tissues [34, 37, 38], exhibiting diverse bioactivities including antineoplastic activities. For example, grincamycin C and D derived from marine Streptomyces lusitanus SCSIO LR32 displayed cytotoxic activities against HepG2 and SW-1990 with $\mathrm{IC}_{50}$ values of $31 \mu \mathrm{M}, 9.7 \mu \mathrm{M}$ for $\mathrm{C}, 31 \mu \mathrm{M}$ and $22 \mu \mathrm{M}$ for $\mathrm{D}$, respectively [39]. Termstrin A from termite-associated Streptomyces sp. BYF63 showed cytotoxicities against melanoma cell line A375 and gastric cancer cell line MGC-803 with $\mathrm{IC}_{50}$ values of 22.76 and $36.65 \mu \mathrm{M}$, respectively, superior to those of referenced adriamycin [37]. 4-deoxy- $\varepsilon$ pyrromycinone, found in endophytic Streptomyces sp. Lz531 isolated from branch tissues of Maytenus hookeri well-known for producing anticancer compounds [38], was obtained again in the extract of LRE541. This study firstly demonstrated anticancer activities of 4-deoxy$\varepsilon$-pyrromycinone against A549, HepG2, SW1990, and 
RKO. Epsilon-pyrromycinone, an anthracycline antibiotic, the yield of which was once increased 12-folds by strain improvement of Streptomyces galilaeus [40]. The antineoplastic activities of epsilon-pyrromycinone towards cancer cell lines were also evaluated for the first time in the study.

\section{Evaluation of preliminary anticancer mechanism of the LRE541 extract}

It is well known that apoptosis and necrosis are two patterns of cell death [41, 42]. Compared to necrosis, an abnormal form of cell death, cell apoptosis regulated by various intra- and extracellular signals and governed by several genes, plays an important role in stress responses, control of normal cell proliferation and development of an organism [43, 44]. Tumorigenesis is closely related to anti-apoptotic pathways [4], and drug induced apoptosis of malignant cells is an efficient strategy in cancer therapy [4, 45]. Our data presented that the LRE541 extract from the endophytic Streptomyces sp. LRE541 validly inhibited the cell viabilities of RKO and 7901 predominantly through the induction of apoptosis in a dose-dependent manner. Apparently, the apoptosis patterns between the two cell lines were remarkably diverse, which suggested distinct mechanisms of the secondary metabolites actions occurring in the two cancer cell lines. Furthermore, previous studies have shown that the cell cycle is likewise intimately associated with the tumorigenesis. Pathological or physiological apoptotic stimuli would greatly affect cell cycle progression, and disorder of cell cycle regulators is a common property of human cancer, which signifies that regulation of cell cycle progression in cancer cells is taken for an available method in the treatment of human malignancies [46, 47]. In this study, the LRE541 extract dramatically inhibited the cell proliferation of RKO and 7901 in a dose-dependent manner by inducing $S$ phase arrest of cell cycle and apoptosis in vitro. Collectively, chemotherapeutics with greater therapeutic efficiency and fewer side effects are of utmost desirability, and drug induced cancer cell death mode plays a vital role in chemotherapy.

\section{Conclusion}

This study characterized the endophytic Streptomyces sp. LRE541 isolated from the root tissues of L. davidii var. unicolor (Hoog) Cotton and examined the cytotoxic activities of secondary metabolites of the isolate against a panel of human malignant cell lines, further detecting the cell apoptosis and cell cycle arrest of RKO and 7901 by flow cytometry revealed a primary mechanism underlying the biological action of the secondary metabolites and might shed light on the potential application of the metabolites in the therapy of RKO and 7901 cell lines.
The chemical profile of the LRE541 extract detected by the UHPLC-MS/MS analysis revealed the presence of antitumor- and antimicrobial-compounds in the extract. Further chemical investigation of the extract of Streptomyces sp. LRE541 led to discovering one prenylated indole diketopiperazine (DKP) alkaloid, elucidated as neoechinulin $A$, a known antitumor agent; two anthraquinones, 4-deoxy- $\varepsilon$-pyrromycinone and epsilon-pyrromycinone both displaying anticancer activities.

\section{Materials and methods}

\section{Sample collection and actinomycetes isolation}

During March 2017, thirty healthy roots of 3-year-old L. davidii var. unicolor (Hoog) Cotton were randomly selected from the lily planting farm of Shaojia Shan $\left(35^{\circ} 57^{\prime} 50.73^{\prime \prime} \mathrm{N}, 103^{\circ} 48^{\prime} 39.69^{\prime \prime} \mathrm{E}, \mathrm{H}: 1868 \mathrm{~m}\right.$ ) in Qilihe District, Lanzhou City, Gansu Province, China. The plant roots were dug out carefully to ensure its integrity, then kept in aseptic plastic bags at $4{ }^{\circ} \mathrm{C}$ and processed within $24 \mathrm{~h}$ after collection. After being washed in running water, the surfaces of the roots were sterilized by sequential immersion in $0.1 \%(\mathrm{v} / \mathrm{v})$ Tween 20 for $5 \mathrm{~min}$, $75 \%(\mathrm{v} / \mathrm{v})$ alcohol for $5 \mathrm{~min}$, a solution of $2 \%(\mathrm{v} / \mathrm{v})$ sodium hypochlorite for $5 \mathrm{~min}$, and $10 \%(\mathrm{w} / \mathrm{v})$ sodium bicarbonate solution for $5 \mathrm{~min}$. Samples were washed in sterile distilled water at least three times to remove surface sterilization agents. Meanwhile, an aliquot $(0.2 \mathrm{~mL})$ of the last washing water was spread on agar plates and incubated at $28{ }^{\circ} \mathrm{C}$ for 7 days to confirm surface sterilization. The surface-sterilized roots were then aseptically sectioned by a commercial blender and spread onto the Gauze's No. 1 media (20 g of soluble starch, $1 \mathrm{~g}$ of $\mathrm{KNO}_{3}$, $0.5 \mathrm{~g}$ of $\mathrm{K}_{2} \mathrm{HPO}_{4}, 0.5 \mathrm{~g}$ of $\mathrm{MgSO}_{4} \cdot 7 \mathrm{H}_{2} \mathrm{O}, 0.5 \mathrm{~g}$ of $\mathrm{NaCl}$, $0.01 \mathrm{~g}$ of $\mathrm{FeSO}_{4} \cdot 7 \mathrm{H}_{2} \mathrm{O}, 20 \mathrm{~g}$ of agar, $\mathrm{pH} 7.2-7.4 ; 121{ }^{\circ} \mathrm{C}$, $20 \mathrm{~min})$ supplemented with cycloheximide $(25 \mathrm{mg} / \mathrm{mL})$ and nystatin $(10 \mathrm{mg} / \mathrm{mL})$, followed by incubation at $23{ }^{\circ} \mathrm{C}$ for up to 2 weeks.

The morphology and growth of suspected actinomycetes were observed every day. Various colony characteristics such as powdery or leathery appearance with concave, convex, crumpled or flate surface, and pigment production were recorded. Representative isolates of 15 colonies with visually distinctive morphologies were selected from 50 initially recovered colonies and re-purified for further studies.

\section{Preliminary screening of endophytic isolates for antimicrobial activities}

All 15 pure isolates were screened for antimicrobial activities by the double layer agar method [29]. Spore suspension of each isolate was inoculated on the Gauze's No. 1 medium and incubated at $23{ }^{\circ} \mathrm{C}$ for 7 days, then overlaid with $5 \mathrm{~mL}$ of $0.6 \%(\mathrm{w} / \mathrm{v})$ soft nutrient agar seeded with 
$500 \mu \mathrm{L}$ of the culture of indicator microorganisms with a turbidity of $0.5 \mathrm{McF}$ arland $\left(10^{7}-10^{8} \mathrm{CFU} / \mathrm{mL}\right)$, including Methicillin-resistant Staphylococcus aureus (MRSA) ATCC25923, Escherichia coli ATCC25922, Pseudomonas aeruginosa ATCC27853, Candida albicans ATCC66415, Staphylococcus saprophyticus (clinical isolate), Enterococcus faecalis (clinical isolate), Diplococcus pneumoniae (clinical isolate). Then, the overlaid plates were incubated at $28{ }^{\circ} \mathrm{C}$ for $24 \mathrm{~h}$, the apparent inhibition zone around each isolate was recorded as positive for antimicrobial activity [29]. Plates with the same medium without actinomycete-like isolates but simultaneously inoculated with the indicator microorganisms were maintained as controls.

\section{Antimicrobial assay of isolate LRE541}

The actinomycete-like isolate that exhibited an apparent inhibition zone against all the tested pathogenic microorganisms was furtherly evaluated by disc diffusion assay [48]. Briefly, isolate LRE541 was inoculated into the Gauze's No. 1 liquid medium performing a small-scale fermentation for 7 days. The sterile filter paper discs (6 $\mathrm{mm}$ diameter) were impregnated into the culture filtrate of LRE541 overnight and air-dried, then placed onto the plates loaded with indicator microorganisms, incubated at $28{ }^{\circ} \mathrm{C}$ for $24 \mathrm{~h}$. The discs loaded with the sterile Gauze's No. 1 liquid filter without inoculating LRE541 were used for controls. The mean value of diameters for the zone of inhibition was calculated from the triplicate assays.

\section{Morphological and physiological characteristics of LRE541 isolate}

To investigate the morphological and cultural characteristics of isolate LRE541, pure culture of LRE541 was examined every day grown on various international Streptomyces project (ISP) media. Micromorphology and sporulation of the culture was examined by the light microscopy (Olympus IX71) using the inclined coverslip technique [49] on the Gauze's No. 1 medium for 7 days. The aerial mycelia and spores were observed under the scanning electron microscopy (SEM) (Hitachi S-3400N) after 14 days of growth on the Gauze's No. 1 medium. Physiological characteristics such as extracellular enzyme activity, carbon/nitrogen source utilization, and temperature/pH tolerance were evaluated following the methods depicted in the Bergey's Manual of Systematic Bacteriology [50] and the ISP [51].

\section{$16 \mathrm{~S}$ rRNA gene sequencing and phylogenetic analysis} The genomic DNA (gDNA) of isolate LRE541 was extracted as described by Orsini et al. [52] with minor adjustment. The universal bacterial primers targeted $16 \mathrm{~S}$
rDNA, $27 \mathrm{~F}\left(5^{\prime}\right.$-AGAGTTTGATCCTGGCTCAG-3') and $1525 \mathrm{R}$ (5'-AAGGAGGTGATCCAGCCGCA-3'), were used for polymerase chain reaction (PCR) amplification following the manufacture's protocol (Takara, Japan) with optimized adjustment. The checked PCR products were directly subjected to cycle sequencing using an ABI3100 automated sequencer (Beijing Sangon Biotech, Beijing, China). The sequenced 16S rRNA gene of isolate LRE541 was matched with the nearest gene sequences of Streptomyces spp. retrieved from a public database using the EzBioCloud tool with Clustal W program. The phylogenetic tree was constructed by using the Maximum Likelihood method [29] and $p$-distance model with bootstrap analysis of 1000 replicates [53] in the MEGA X package.

The 16S rRNA gene sequence of isolate LRE541 had been submitted to the GenBank nucleotide sequence databases under accession no. MK138546.

\section{Fermentation and extraction of secondary metabolites from LRE541}

Isolate LRE541 cultured on a slant agar medium was inoculated into a $500 \mathrm{~mL}$ Erlenmeyer flask containing $100 \mathrm{~mL}$ of the seed medium consisting of $15 \mathrm{~g} / \mathrm{L}$ soluble starch, $10 \mathrm{~g} / \mathrm{L}$ soybean powder, $1 \mathrm{~g} / \mathrm{L} \mathrm{NaCl}, 5 \mathrm{~g} / \mathrm{L}$ glucose, $5 \mathrm{~g} / \mathrm{L}$ tryptone, and $5 \mathrm{~g} / \mathrm{L} \mathrm{CaCO}_{3}(\mathrm{pH}$ 7.3). The seed media were cultivated on a rotary shaker $(150 \mathrm{rpm})$ at $28{ }^{\circ} \mathrm{C}$ for 3 days. Then $11 \mathrm{~mL}$ of seed broth was transferred into a 1000-mL Erlenmeyer flask containing $500 \mathrm{~mL}$ Gause's liquid medium, and incubated at $28{ }^{\circ} \mathrm{C}$, $150 \mathrm{rpm}$ for 9 days. After the fermentation process, the biomass was discarded by centrifugation at $10,000 \times g$ for $20 \mathrm{~min}$ while the supernatant was harvested and extracted three times with an equal volume of ethyl acetate. Then the ethyl acetate fractions were concentrated at $40{ }^{\circ} \mathrm{C}$ in a rotary vacuum distillation apparatus and dissolved in DMSO $(1 \mathrm{mg} / \mathrm{mL})$ for the investigation of antitumor activities.

\section{In vitro cytotoxic assay of the extract from LRE541 Cell culture}

The antitumor activity of the LRE541 extract was examined against a wide variety of cell lines, including nine human cancer cell lines (HepG-2, SW-1190, CAL-27, 7901, RKO, MCF-7, Hela, K562, A549) and one normal human pulmonary artery endothelial cell line (HPAEC), which were purchased from the Shanghai Institute of Biochemistry and Cell Biology, Chinese Academy of Sciences. The cells were incubated in RPMI-1640 medium supplemented with $10 \%(\mathrm{v} / \mathrm{v})$ fetal bovine serum (FBS), $2 \mathrm{mM}$ glutamine and 100 units/mL streptomycin-penicillin, then maintained in a humidified atmosphere of $5 \%$ $\mathrm{CO}_{2}$ at $37^{\circ} \mathrm{C}$. 


\section{Cytotoxicity assay}

The cell survival rate was evaluated using the MTT assay [31]. In short, the cells were seeded at a density of $1 \times 10^{4}$ cells/well in 96-well plates for $24 \mathrm{~h}$, then the medium was replaced with a fresh medium containing different concentrations of the LRE541 extract for $48 \mathrm{~h}$. Cells treated with DMSO alone were set as negative controls, and cis-platinum was used as the positive control. Later, $10 \mu \mathrm{L}$ MTT $(5 \mathrm{mg} / \mathrm{mL})$ reagent was added to each well and incubated for an additional $4 \mathrm{~h}$ at $37^{\circ} \mathrm{C}$. Absorbance $(490 \mathrm{~nm})$ of the medium was measured using a microplate reader (Thermo Scientific Multiskan GO, Finland).

\section{Cell apoptosis analysis}

RKO and 7901 cells were seeded in 6-well plates for $24 \mathrm{~h}$, then incubated with LRE541 extract of various concentrations $(0,0.5,1$, and $2 \mu \mathrm{g} / \mathrm{mL})$ for $48 \mathrm{~h}$. Then, both of the cells were collected and washed with phosphate-buffered saline (PBS) (0.01 M; pH 7.4) three times. Afterwards, cell samples were stained with fluorescein 5-isothiocyanate (FITC)-conjugated annexin V and propidium iodide (PI) following the manufacturer's instructions (Zoman Biotech, Beijing, China). Data was obtained and analyzed using a FACS-Canto flow cytometer (BD Biosciences, San Jose, CA, USA) with FlowJo software.

\section{Cell cycle analysis}

Cell cycle analysis was also performed by flow cytometry [54]. In brief, RKO and 7901 cells were plated in 6-well plates for $24 \mathrm{~h}$ and then incubated with the LRE541 extract of various concentrations $(0,0.5,1$, and $2 \mu \mathrm{g} / \mathrm{mL})$ for $48 \mathrm{~h}$. Then, the cells were harvested and washed with PBS three times, and the percentages of cells in the $\mathrm{G}_{0} /$ $\mathrm{G}_{1}, \mathrm{~S}$, and $\mathrm{G}_{2} / \mathrm{M}$ phases were analyzed using the FACSCanto flow cytometer (BD Biosciences, San Jose, CA, USA) in the presence of propidium iodide buffer $(50 \mu \mathrm{g} /$ $\mathrm{mL}$; $\mathrm{pH}$ 7.4) with RNase (100 $\mu \mathrm{g} / \mathrm{mL} ; \mathrm{pH} 7.4)$ (Zoman Biotech, Beijing, China).

\section{Metabolite profiles by the UHPLC-MS/MS analysis}

The LRE541 extract was subjected to a Vanquish UHPLC system equipped with an Orbitrap Q Exactive series mass spectrometer (Thermo Fisher) for the metabolite profile analysis. The processed samples were injected onto a Hyperil Gold column $(100 \times 2.1 \mathrm{~mm}$, $1.9 \mu \mathrm{m}$ ) using a 16 -min linear gradient at a flow rate of $0.2 \mathrm{~mL} / \mathrm{min}$. The eluents for the positive polarity mode were eluent A ( $0.1 \%$ formic acid in water) and eluent $\mathrm{B}$ (methanol), and for the negative polarity mode were eluent A (5 mM ammonium acetate, $\mathrm{pH}$ 9.0) and eluent B (methanol). The solvent gradient was set as follows:
2\% B, 1.5 min; 2-100\% B, 12.0 min; $100 \%$ B, 14.0 min; 100-2\% B, $14.1 \mathrm{~min} ; 2 \%$ B, 17 min. Q Exactive series mass spectrometer was operated in the positive/negative polarity mode with a spray voltage of $3.2 \mathrm{kV}$, capillary temperature of $320{ }^{\circ} \mathrm{C}$, sheath gas flow rate of 35 arb, and aux gas flow rate of 10 arb.

\section{Purification and characterization of bioactive metabolites from LRE541 extract}

The ethyl acetate extract of LRE541 was separated and purified on an HP-20 macroporous resin (Mitsubishi, Japan) column and eluted with gradient mixtures of $\mathrm{H}_{2} \mathrm{O}-\mathrm{EtOH}(70: 30,50: 50,20: 80)$ to give three fractions (A-C). After evaporation of the menstruum in vacuo, the fraction $\mathrm{C}(0.5 \mathrm{~g})$ was resolved by chromatography on a silica gel column eluted with $\mathrm{CHCl}_{3} / \mathrm{EtOAc}$ mixtures with a growing polarity $(25: 1-1: 1, \mathrm{v} / \mathrm{v})$ to obtain six fractions (C1-6). Bioactivity assays (in vitro antitumor activity) indicated that $\mathrm{C} 3\left(\mathrm{CHCl}_{3} / \mathrm{EtOAc}, 10: 1\right)$ and $\mathrm{C} 4$ $\left(\mathrm{CHCl}_{3} /\right.$ EtOAc, $\left.7: 1\right)$ fractions were cytotoxic in vitro. The active fractions ( $\mathrm{C} 3$ and 4$)$ were repeatedly purified and separated on Sephadex $\mathrm{LH}-20\left(\mathrm{CHCl}_{3}: \mathrm{MeOH}\right.$, 1:1) by semi-preparative HPLC (NP7001C, C18, $5 \mu \mathrm{m}$, $250 \times 10 \mathrm{~mm}$ inner diameter; Hanbon Sci. \& Tech.) to afford compounds (1)-(3) (1, 1.2, $1.5 \mathrm{mg}$ of each).

Structural identification of the purified metabolites was elucidated on Bruker DRX-400 spectrometer (Bruker, Rheinstetten, Germany) by using spectroscopic techniques for ${ }^{1} \mathrm{H}$ and ${ }^{13} \mathrm{C}\left(400 \mathrm{MHz}\right.$ for ${ }^{1} \mathrm{H}$ and $100 \mathrm{MHz}$ for $\left.{ }^{13} \mathrm{C}\right)$. Chemical shifts were reported in ppm. $(\delta)$, using residual $\mathrm{CHCl}_{3}\left(\delta_{\mathrm{H}} 7.26 \mathrm{ppm} ; \delta_{\mathrm{C}} 77.0\right)$ and $\left(\mathrm{CH}_{3}\right)_{2} \mathrm{CO}\left(\delta_{\mathrm{H}} 2.05 \mathrm{ppm} ; \delta_{\mathrm{C}} 29.84\right)$ as an internal standard, with coupling constants $(J)$ in Hz. Moreover, the HMBC and HSQC techniques were also performed for supporting the ${ }^{1} \mathrm{H}$ and ${ }^{13} \mathrm{C}$ spectroscopic analysis.

\section{Statistical analysis}

Data were expressed as the means \pm SD for at least three independent experiments. SPSS software was applied to perform the statistical analysis, and the statistical differences between the two groups were assessed by Student's t-test. $P<0.05$ was used as the criterion for statistical significance.

\section{Abbreviations}

PBS: Phosphate buffered saline; MTT: 3-(4,5-Dimethylthiazol-2-yl)-2,5-diphenyl tetrazolium bromide; DMSO: Dimethyl sulfoxide; SEM: Scanning electron microscopy; ANOVA: Analysis of variance; PI: Propidium iodide; FBS: Fetal bovine serum; $I C_{50}$ : Inhibition concentration of $50 \%$ growth; EtOAc: Ethyl acetate; rpm: Rotations per minute; TLC: Thin-layer chromatography; HPLC: High performance liquid chromatography; w/v: Weight/volume; v/v: Volume/ volume. 


\section{Supplementary Information}

The online version contains supplementary material available at https://doi. org/10.1186/s12934-021-01706-z.

Additional file 1: Table S1. Antimicrobial activities of the actinomycetelike isolates from the root tissues of Lilium davidii var. unicolor (Hoog) Cotton. Table S2. Chemical constituents of antitumor-(1-39), antioxidant-(40-49), and antimicrobial-(50-65) compounds identified in the LRE541 extract by the UHPLC-MS/MS analysis. Figure S1. Total iron chromatography of the LRE541 extract by the UHPLC-MS/MS analysis. Figure S2. Chemical structures of the antitumor (1-39)-, antioxidant (40-49)-, and antimicrobial (50-65)-compounds from the LRE541 extract. Figure S3. ${ }^{13} \mathrm{C}$ NMR spectrum of epsilon-pyrromycinone in $\mathrm{CDCl}_{3}(100 \mathrm{MHz})$. Figure $\mathbf{S 4}$. ${ }^{1} \mathrm{H}$ NMR spectrum of Epsilon-pyrromycinone in $\mathrm{CDCl}_{3}(400 \mathrm{MHz})$. Figure S5. ${ }^{13} \mathrm{C}$ NMR spectrum of 4-deoxy- $\varepsilon$-pyrromycinone in $\mathrm{CDCl}_{3}(100 \mathrm{MHz})$. Figure S6. ${ }^{1} \mathrm{H}$ NMR spectrum of 4-deoxy-e-pyrromycinone in $\mathrm{CDCl}_{3}$ $(400 \mathrm{MHz})$. Figure $\mathrm{S7}$. HMBC spectrum of 4-deoxy-e-pyrromycinone in $\mathrm{CDCl}_{3}$. Figure S8. $\mathrm{HSQC}$ spectrum of 4-deoxy- $\varepsilon$-pyrromycinone in $\mathrm{CDCl}_{3}$. Figure S9. ${ }^{13} \mathrm{C}$ NMR spectrum of Neoechinulin $\mathrm{A}$ in $\mathrm{CDCl}_{3}(100 \mathrm{MHz})$. Figure S10. ${ }^{1} \mathrm{H}$ NMR spectrum of Neoechinulin $\mathrm{A}$ in $\mathrm{CDCl}_{3}(400 \mathrm{MHz})$.

\section{Acknowledgements}

Not applicable.

\section{Authors' contributions}

$\mathrm{CZ}, \mathrm{AM}$ and $\mathrm{KJ}$ planned and designed the research. BC, SC, XQ, JL and AM conducted the experiments and analyzed the data. AM wrote the manuscript. All authors were involved in revising the manuscript critically. All authors read and approved the final manuscript.

\section{Funding}

The work was supported by the National Natural Science Foundation of China (31522013) and the Natural Science Foundation of Gansu Province, China (No. 21 JR7RA805)

\section{Availability of data and materials}

All data generated or analyzed during the study were included in this paper and its Additional file 1.

\section{Declarations}

\section{Ethics approval and consent to participate}

Not applicable.

\section{Consent for publication}

All authors give consent to publish the research in the microbial cell factories.

\section{Competing interests}

The authors declare that they have no competing interests.

\section{Author details \\ ${ }^{1}$ State Key Laboratory of Grassland Agro-Ecosystems, School of Life Sciences, Lanzhou University, Lanzhou 730000, Gansu, China. ${ }^{2}$ Yuzhong Mountain Ecosystem Field Observation and Research Station, Lanzhou University, Lan- zhou 730000, Gansu, China. ${ }^{3}$ Department of Animal and Biomedical Sciences, School of Life Sciences, Lanzhou University, Lanzhou 730000, China. ${ }^{4}$ Life Science and Engineering College of Northwest University for Nationalities, Lanzhou 730000, China. ${ }^{5}$ College of Agronomy, Gansu Agricultural University, Lanzhou 730070, China.}

Received: 5 August 2021 Accepted: 10 November 2021 Published online: 04 December 2021

\section{References}

1. Sara C, Maria P, Maeve K, Graham P, Denis C. Innovative technologies changing cancer treatment. Cancers. 2018;10:208.
2. Holohan C, Schaeybroeck SV, Longley DB, Johnston PG. Cancer drug resistance: an evolving paradigm. Nat Rev Cancer. 2013;13:714-26. https://doi.org/10.1038/nrc3599.

3. Hussain S, Singh A, Nazir SU, Tulsyan S, Khan A, Kumar R, Bashir N, Tanwar P, Mehrotra R. Cancer drug resistance: a fleet to conquer. J Cell Biochem. 2019;120:14213-25. https://doi.org/10.1002/jcb.28782.

4. Kerr JF, Winterford CM, Harmon BV. Apoptosis. Its significance in cancer and cancer therapy. Cancer. 1994;73:2013-26. https://doi.org/10.1002/ 1097-0142(19940415)73:8\%3c2013::aid-cncr2820730802\%3e3.0.co;2-j.

5. Cao K, Tait SW. Apoptosis and cancer: force awakens, phantom menace, or both? Int Rev Cell Mol Biol. 2018;337:135-52. https://doi.org/10.1016/ bs.ircmb.2017.12.003.

6. Campbell KJ, Tait SW. Targeting $\mathrm{BCL}-2$ regulated apoptosis in cancer. Open Biol. 2018;8:180002. https://doi.org/10.1098/rsob.180002.

7. Hayakawa Y, Kuriyama T, Ibusuki Y, Kimata S. Pyroxazone, a new neuroprotective compound from Streptomyces sp. RAN54. J Antibiot. 2018;71:9624. https://doi.org/10.1038/s41429-018-0085-4.

8. Tan TH, Chan KG, Pusparajah P, Yin WF, Khan TM, Lee LH, Goh BH. Mangrove derived Streptomyces sp. MUM265 as a potential source of antioxidant and anticolon-cancer agents. BMC Microbiol. 2019;19:38-44. https://doi.org/10.1186/s12866-019-1409-7.

9. Bieber B, Nüske J, Ritzau M, Grafe U. Alnumycin a new naphthoquinone antibiotic produced by an endophytic Streptomyces sp. J Antibiot. 1998;51:381-2. https://doi.org/10.7164/antibiotics.51.381.

10. Ser HL, Palanisamy UD, Yin WF, Chan KG, Goh BH, Lee LH. Streptomyces malaysiense sp. nov.: a novel Malaysian mangrove soil actinobacterium with antioxidative activity and cytotoxic potential against human cancer cell lines. Sci Rep. 2016;6:24247-59. https://doi.org/10.1038/srep24247.

11. Remsing LL, González AM, Nur-e-Alam M, Fernández-Lozano MJ, Braña AF, Rix U, Oliveira MA, Méndez C, Salas JA, Rohr J. Mithramycin SK, a novel antitumor drug with improved therapeutic index, mithramycin SA, and demycarosyl-mithramycin SK: three new products generated in the mithramycin producer Streptomyces argillaceus through combinatorial biosynthesis. J Am Chem Soc. 2003;125:5745-53. https://doi.org/10.1021/ ja034162h.

12. Taechowisan T, Lu C, Shen Y, Lumyong S. Antitumor activity of 4-arylcoumarins from endophytic Streptomyces aureofaciens CMUAc130. J Cancer Res Ther. 2007;3:86-91. https://doi.org/10.4103/0973-1482.34685.

13. Zhang R, Han X, Xia Z, Luo X, Wan C, Zhang L. Streptomyces /uozhongensis sp. nov., a novel actinomycete with antifungal activity and antibacterial activity. Antonie Van Leeuwenhoek. 2017;110:195-203. https://doi.org/10. 1007/s10482-016-0790-6.

14. Wang L, Qiu P, Long XF, Zhang S, Zeng ZG, Tian YQ. Comparative analysis of chemical constituents, antimicrobial and antioxidant activities of ethyl acetate extracts of Polygonum cuspidatum and its endophytic actinomycete, Streptomyces sp. A0916. Chin J Nat Med. 2016;14:117-23. https://doi. org/10.1016/s1875-5364(16)60004-3.

15. Perez Baz J, Canedo LM, Fernandez Puentes JL, Silva Elipe MV. Thiocoraline, a novel depsipeptide with antitumor activity produced by a marine Micromonospora. II. Physico-chemical properties and structure determination. J Antibiot. 1997;50:738-41. https://doi.org/10.7164/antibiotics.50. 738.

16. Schneider K, Keller S, Wolter FE, Roglin L, Beil W, Seitz O, Nicholson G, Bruntner C, Riedlinger J, Fiedler HP, Sussmuth RD. Proximicins A, B, and $C$-antitumor furan analogues of netropsin from the marine actinomycete Verrucosispora induce upregulation of p53 and the cyclin kinase inhibitor p21. Angew Chem Int Ed Engl. 2008;47:3258-61. https://doi.org/10.1002/ anie.200705295.

17. Golinska P, Wypij M, Agarkar G, Rathod D, Dahm H, Rai M. Endophytic actinobacteria of medicinal plants: diversity and bioactivity. Antonie Van Leeuwenhoek. 2015;108:267-89. https://doi.org/10.1007/ s10482-015-0502-7.

18. Khieu T-N, Liu M-J, Nimaichand S, Quach N-T, Chu-Ky S, Phi Q-T, Vu T-T, Nguyen T-D, Xiong Z, Prabhu DM, Li W-J. Characterization and evaluation of antimicrobial and cytotoxic effects of Streptomyces sp. HUST012 isolated from medicinal plant Dracaena cochinchinensis Lour. Front Microbiol. 2015;6:574-574. https://doi.org/10.3389/fmicb.2015.00574.

19. Hui H, Jin H, Li X, Yang $X$, Cui H, Xin A, Zhao R, Qin B. Purification, characterization and antioxidant activities of a polysaccharide from the roots of Lilium davidii var. unicolor Cotton. Int J Biol Macromol. 2019;135:1208-16. https://doi.org/10.1016/j.ijbiomac.2019.06.030. 
20. Barka EA, Vatsa P, Sanchez L, Gaveau-Vaillant N, Jacquard C, Meier-Kolthoff JP, Klenk HP, Clément C, Ouhdouch Y, van Wezel GP. Taxonomy, physiology, and natural products of actinobacteria. Microbiol Mol Biol Rev. 2016;80:1-43. https://doi.org/10.1128/mmbr.00019-15.

21. Gali-Muhtasib H, Hmadi R, Kareh M, Tohme R, Darwiche N. Cell death mechanisms of plant-derived anticancer drugs: beyond apoptosis. Apoptosis. 2015;20:1531-62. https://doi.org/10.1007/s10495-015-1169-2.

22. Kaufmann SH, Earnshaw WC. Induction of apoptosis by cancer chemotherapy. Exp Cell Res. 2000;256:42-9.

23. Pettit GR, Hogan F, Xu J-P, Tan R, Nogawa T, Cichacz Z, Pettit RK, Du J, Ye Q-H, Cragg GM, Herald CL, Hoard MS, Goswami A, Searcy J, Tackett L, Doubek DL, Williams L, Hooper JNA, Schmidt JM, Chapuis J-C, Tackett DN, Craciunescu F. Antineoplastic agents. 536. New sources of naturally occurring cancer cell growth inhibitors from marine organisms, terrestrial plants, and microorganisms. J Nat Prod. 2008;71:438-44. https://doi.org/ 10.1021/np700738k.

24. Wijesekara I, Li YX, Vo TS, Ta QV, Ngo DH, Kim SK. Induction of apoptosis in human cervical carcinoma HeLa cells by neoechinulin A from marinederived fungus Microsporum sp. Process Biochem. 2013;48:68-72.

25. Deeble VJ, Lindley HK, Fazeli MR, Cove JH, Baumberg S. Depression of streptomycin production by Streptomyces griseus at elevated growth temperature: studies using gene fusions. Microbiology. 1995;141(Pt 10):2511-8. https://doi.org/10.1099/13500872-141-10-2511.

26. Srivibool R, Kurakami K, Sukchotiratana M, Tokuyama S. Coastal soil actinomycetes: thermotolerant strains producing $\mathrm{N}$-acylamino acid racemase. ScienceAsia. 2004;30:123-6.

27. Basilio A, González I, Vicente MF, Gorrochategui J, Cabello A, González A, Genilloud O. Patterns of antimicrobial activities from soil actinomycetes isolated under different conditions of $\mathrm{pH}$ and salinity. J Appl Microbiol. 2003;95:814-23. https://doi.org/10.1046/j.1365-2672.2003.02049.x.

28. Zakalyukina YV, Zenova GM, Zvyagintsev DG. Peculiarities of growth and morphological differentiation of acidophilic and neutrophilic soil streptomycetes. Microbiology. 2004;73:74-8. https://doi.org/10.1023/b: mici.0000016372.52239.dd.

29. Ma A, Zhang $X$, Jiang $K$, Zhao C, Liu J, Wu M, Wang Y, Wang M, Li J, Xu S. Phylogenetic and physiological diversity of cultivable actinomycetes isolated from alpine habitats on the Qinghai-Tibetan Plateau. Front Microbiol. 2020;11: 555351. https://doi.org/10.3389/fmicb.2020.555351.

30. Romero-Rodríguez A, Maldonado-Carmona N, Ruiz-Villafán B, Koirala N, Rocha D, Sánchez S. Interplay between carbon, nitrogen and phosphate utilization in the control of secondary metabolite production in Streptomyces. Antonie Van Leeuwenhoek. 2018;111:761-81. https://doi.org/10. 1007/s10482-018-1073-1.

31. Lee CC, Houghton P. Cytotoxicity of plants from Malaysia and Thailand used traditionally to treat cancer. J Ethnopharmacol. 2005;100:237-43. https://doi.org/10.1016/j.jep.2005.01.064.

32. Katoch M, Singh G, Sharma S, Gupta N, Sangwan PL, Saxena AK. Cytotoxic and antimicrobial activities of endophytic fungi isolated from Bacopa monnieri (L.) Pennell (Scrophulariaceae). BMC Complement Altern Med. 2014;14:52-60. https://doi.org/10.1186/1472-6882-14-52.

33. Yagi R, Doi M. Isolation of an antioxidative substance produced by Aspergillus repens. Biosci Biotechnol Biochem. 1999;63:932-3.

34. Greco G, Turrini E, Catanzaro E, Fimognari C. Marine anthraquinones: pharmacological and toxicological issues. Mar Drugs. 2021;19:272. https://doi.org/10.3390/md19050272.

35. Bovio E, Fauchon M, Toueix Y, Mehiri M, Varese GC, Hellio C. The spongeassociated fungus Eurotium chevalieri MUT 2316 and its bioactive molecules: potential applications in the field of antifouling. Mar Biotechnol. 2019;21:743-52. https://doi.org/10.1007/s10126-019-09920-y.

36. Kim K-S, Cui X, Lee D-S, Sohn JH, Yim JH, Kim Y-C, Oh H. Anti-inflammatory effect of neoechinulin a from the marine fungus Eurotium sp. SF-5989 through the suppression of NF-KB and p38 MAPK pathways in lipopolysaccharide-stimulated RAW2647 macrophages. Molecules. 2013;18:13245-59. https://doi.org/10.3390/molecules181113245.

37. Zhang L, Song T, Wu J, Zhang S, Yin C, Huang F, Hang Y, Abbas N, Liu X, Zhang Y. Antibacterial and cytotoxic metabolites of termite-associated Streptomyces sp. BYF63. J Antibiot. 2020;73:766-71. https://doi.org/10. 1038/s41429-020-0334-1.

38. Zhao PJ, Wang HX, Li GH, Li HD, Liu J, Shen YM. Secondary metabolites from endophytic Streptomyces sp. Lz531. Chem Biodivers. 2007:4:899_ 904. https://doi.org/10.1002/cbdv.200790078.
39. Lai Z, Yu J, Ling H, Song Y, Yuan J, Ju J, Tao Y, Huang H. Grincamycins I-K, cytotoxic angucycline glycosides derived from marine-derived actinomycete Streptomyces lusitanus SCSIO LR32. Planta Med. 2018;84:201-7. https://doi.org/10.1055/s-0043-119888.

40. Královcová E, Blumauerová M, Vaněk Z. Strain improvement in Streptomyces galilaeus, a producer of anthracycline antibiotics galirubins. Folia Microbiol. 1977;22:321-8.

41. Harmeet M, Gores GJ, Lemasters JJ. Apoptosis and necrosis in the liver: a tale of two deaths? Hepatology. 2006;43:S31-44. https://doi.org/10.1002/ hep.21062.

42. Chen Q, Kang J, Fu C. The independence of and associations among apoptosis, autophagy, and necrosis. Signal Transduct Target Ther. 2018:3:18-29. https://doi.org/10.1038/s41392-018-0018-5.

43. Schultz DR, Harringto Jr WJ. Apoptosis: programmed cell death at a molecular level. Semin Arthritis Rheum. 2003;32:345-69. https://doi.org/ 10.1053/sarh.2003.50005.

44. Susan E. A review of programmed cell death. Toxicol Pathol. 2007;35:495516. https://doi.org/10.1080/01926230701320337.

45. Ghobrial IM, Witzig TE, Adjei AA. Targeting apoptosis pathways in cancer therapy. CA Cancer J Clin. 2005:55:178-94. https://doi.org/10.3322/canjc lin.55.3.178.

46. Kar S. Unraveling cell-cycle dynamics in cancer. Cell Syst. 2016;2:8-10. https://doi.org/10.1016/j.cels.2016.01.007.

47. Schwartz GK, Shah MA. Targeting the cell cycle: a new approach to cancer therapy. J Clin Oncol. 2005;23:9408-21. https://doi.org/10.1200/ jco.2005.01.5594.

48. Das R, Romi W, Das R, Sharma HK, Thakur D. Antimicrobial potentiality of actinobacteria isolated from two microbiologically unexplored forest ecosystems of Northeast India. BMC Microbiol. 2018;18:71-71. https://doi. org/10.1186/s12866-018-1215-7.

49. Kumar V, Naik B, Gusain O, Bisht GS. An actinomycete isolate from solitary wasp mud nest having strong antibacterial activity and kills the Candida cells due to the shrinkage and the cytosolic loss. Front Microbiol. 2014;5:446-446. https://doi.org/10.3389/fmicb.2014.00446.

50. Brenner DJ, Krieg NR, Staley JT. Bergey's manual ${ }^{\circledR}$ of systematic bacteriology. Baltimore: Williams \& Wilkins; 2005.

51. Shirling EB, Gottlieb D. Methods for characterization of Streptomyces species. Int J Syst Bacteriol. 1966;16:313-40. https://doi.org/10.1099/00207 713-16-3-313.

52. Orsini M, Romano-Spica V. A microwave-based method for nucleic acid isolation from environmental samples. Lett Appl Microbiol. 2001;33:1720. https://doi.org/10.1046/j.1472-765x.2001.00938.x.

53. Felsenstein J. Confidence limits on phylogenies: an approach using the bootstrap. Evolution. 1985;39:783-91. https://doi.org/10.1111/j.15585646.1985.tb00420.x.

54. Tian R, Li Y, Gao M. Shikonin causes cell-cycle arrest and induces apoptosis by regulating the EGFR-NF-KB signalling pathway in human epidermoid carcinoma A431 cells. Biosci Rep. 2015;35:e00189. https://doi. org/10.1042/BSR20150002.

\section{Publisher's Note}

Springer Nature remains neutral with regard to jurisdictional claims in published maps and institutional affiliations.
Ready to submit your research? Choose BMC and benefit from:
- fast, convenient online submission
- thorough peer review by experienced researchers in your field
- rapid publication on acceptance
- support for research data, including large and complex data types
- gold Open Access which fosters wider collaboration and increased citations
- maximum visibility for your research: over 100M website views per year

At BMC, research is always in progress.

Learn more biomedcentral.com/submissions 